\title{
Analysis of Food Access Status among Farming Households in Southern Part of Gombe State, Nigeria
}

\section{Hosea Danladi, Catherine O. OJo (PhD)}

\author{
Department of Agricultural Economics, University of Maiduguri, PMB 1069 Borno State, \\ Nigeria
}

\section{ARTICLE INFO}

Article No.: 021018022

Type: Research

DOI: 10.15580/GJAS.2018.3.021018022

Submitted: 10/02/2018

Accepted: 19/02/2018

Published: $31 / 03 / 2018$

*Corresponding Author

Hosea Danladi

E-mail: hoseadanladi@

yahoo.com

Phone: +2347033364331

Keywords: Farming Household, Food Access, Food Insecurity, Gombe State, Nigeria
ABSTRACT

This study analyzed food access status among farming households in southern part of Gombe state, Nigeria. Multi-stage sampling technique was used to select 120 respondents from eight villages in the study area. Descriptive and inferential statistics were used to analyze the data. Descriptive statistics were used to summarize the socio-economic characteristics of the respondents. Most respondents (68.3 percent) were male and married with average household size of 7 persons. Household Food Insecurity Access Scale (HFIAS) developed by Food and Nutrition Assistance (FANTA) of the USAID (2004) was used to determine the status of the farming household food insecurity. The HFIAS score revealed that about 27 percent of the farming households were food secure, 35 percent mildly food insecure, $\mathbf{1 8 . 3}$ percent moderately food insecure and $\mathbf{2 0}$ percent were severely food insecure. A simple regression analysis showed that income positively and significantly (1\%) contributed to household food security with an $\mathbf{R}^{2}$ of 0.6801 showing that income played an important role in achieving household food security among farming households. The study concludes that adequate resources to access food by food deficient households could significantly influence the status of food security among the rural households. It was recommended that additional sources of livelihood to include off-farm remunerative activities through skills acquisition and increased agricultural (onfarm) production by subsidizing inputs to be the option policy in achieving rural household food security. 


\section{INTRODUCTION}

Food and Agriculture Organization (FAO) of the united nations (2001) gave the most widely accepted definition of food security as a situation that exist when all people, at all times, have physical and economic access to sufficient, safe and nutritious food to meet the dietary needs and food preferences for an active and healthy life. This definition reveals the multidimensional concept of household food security. It integrates food stability, access, availability of nutritionally adequate food for utilization. Food stability or sustainability is achieved when there is an uninterrupted supply of food for farm households through either own production or market supply. On the other hand, food availability for farm households in rural areas is assurance of accessing required food through any means when the need arises. Food access and utilization is having adequate resources economic, physical or socio-cultural means of obtaining food for a nutritious diet. Food security status at household level is a balance between availability of and accessibility to sufficient food. Food availability among rural farm households can be achieved through increased agricultural production but access to food by food deficient households is more or less a function of economic resources available to households. This means that where resources become limited or absent, household food security status changes.

Food insecurity exists when there is absence or inadequate availability and supply of food for a healthy living (Bokeloh et al., 2009). It also refers to inability of households or individuals to meet the required food need for consumption as a result of famine, hike in food prices, political instability among other factors (Maharjan and Chhetri, 2006). Worldwide, about 852 million people are chronically hungry because of extreme poverty while up to 2 billion are food insecure at various levels due to varying degrees of poverty (FAO, 2003). Most of the world food insecure countries are in Africa and many of these countries face severe poverty and hunger. Even in the continent, sub-Saharan African countries are the most prevalent in hunger, malnutrition and famine due to subsistence nature of agriculture, economic and political instability, and high population growth rate among others (Babatunde et al., 2007). In Nigeria for instance, food production has not balanced with food demand of the increasing population. While food demand increases at 2.5 percent, population increases at 3.2 percent annually (Oluyole and Lawal, 2008).Imbalance between growing population and inadequate food supply result in hunger among farming households and hunger is the manifestation of inadequate food consumption among individuals (FAO, 2010).

In Nigeria, the rural population is mostly agrarian and usually practices subsistence agriculture which often times yields farm output that is inadequate for a year round supply to meet the dietary needs of the farm households. The problems of subsistence farming, growing population and inadequate farm output make this study necessary to know the status of food insecurity among rural households in the study area.

\section{MATERIALS AND METHODS}

This study was carried out in southern part of Gombe state, north eastern region of Nigeria. Southern part of Gombe state lies between $9^{\circ} 30^{\prime}$ and $12^{\circ} 30^{\prime} \mathrm{N}$ and $8^{\circ} 45^{\prime}$ and $11^{\circ} 45^{\prime} \mathrm{E}$ of the equator. It shares boundaries with northern part of the state to the north, Taraba state to the south, Adamawa state to the south east and Borno state to the south west. The region comprises of four local government areas. The vegetation is mainly guinea savannah grass land with concentration of wood lands in the south east and south west.

Structured questionnaire was used as instrument for data collection. Multi-stage sampling technique was used for sampling respondents. Southern part of Gombe state consists of four Local Government Areas (LGAs) with equal number of wards all of which are actively involved in farming activities. One ward each was selected from each LGA in the first stage. The second stage involved random selection of two (2) villages from each of the selected wards to give a total of eight (8) villages. In the last stage, 120 households were proportionately drawn from the selected villages.

Descriptive and inferential statistics were used to analyze the data. The descriptive statistics used include frequency, percentages and means. Household Food Insecurity Access Scale (HFIAS) was also used. The inferential statistics used was a simple regression model used to analyze the effect of household income on food accessibility among farming households.

The HFIAS is a food access measure which was developed by Food and Nutrition Technical Association of the USAID in 2004. The tool is composed of nine standard questions that provide information on household's diet in relation to their ability to access food using the available resources. Households were asked about anxiety of accessing food, modification in household diet and food consumption behavior due to limited resources of households. It is an effective technique because it measures the recent household's food access situation within the last four (4) weeks (30 days). The score ranges $0-27$ as the minimum and maximum score respectively. A higher HFIAS score is indicative of poorer access to food and greater household food insecurity and vice versa. Four degrees of severity of food insecurity were developed adopting the approach of FANTA, 2004. These were food secure or better access to food ranges (0-1), mildly food insecure (2-7), moderately food insecure (8-14) and severely food insecure (15-27).

Inferential statistics (simple regression model) was used to determine the relationship between food accessibility and income of household head.

The simple regression model used for this study was expressed as: 
$\ln Y=X+e$

Where:

$Y=$ index of household food accessibility

$\mathrm{X}=$ household income (Farm and off farm incomes)

$\mathrm{e}=$ error term

\section{RESULTS AND DISCUSSIONS}

Table 1 shows the result of socio-economic characteristics of the rural farming households in the study area.

Table 1: Socio-economic characteristics of farm households

\begin{tabular}{|c|c|c|c|}
\hline Variable & Mean & Frequency & Percentage (\%) \\
\hline \multicolumn{4}{|l|}{ Age (years) } \\
\hline $19-20$ & & 3 & 2.50 \\
\hline $21-30$ & & 23 & 19.16 \\
\hline $31-40$ & & 25 & 20.83 \\
\hline $41-50$ & & 54 & 45.00 \\
\hline \multirow[t]{2}{*}{ Above 50} & & 15 & 12.50 \\
\hline & 40 & & \\
\hline \multicolumn{4}{|l|}{ Sex } \\
\hline Male & & 82 & 68.3 \\
\hline Female & & 38 & 31.7 \\
\hline \multicolumn{4}{|l|}{ Marital Status } \\
\hline Married & & 101 & 84.2 \\
\hline Single & & 7 & 5.8 \\
\hline Widowed/widower & & 9 & 7.5 \\
\hline Divorced & & 3 & 2.5 \\
\hline \multicolumn{4}{|l|}{ Educational Level } \\
\hline Tertiary & & 18 & 15 \\
\hline Secondary & & 57 & 47.5 \\
\hline Primary & & 21 & 17.5 \\
\hline Religious & & 13 & 10.8 \\
\hline No education & & 11 & 9.2 \\
\hline \multicolumn{4}{|c|}{ Household Size (persons) } \\
\hline Less than 3 & & 5 & 4.2 \\
\hline $3-5$ & & 37 & 30.8 \\
\hline $6-10$ & & 51 & 42.5 \\
\hline $11-13$ & & 15 & 12.5 \\
\hline \multirow[t]{2}{*}{ Above 13} & & 12 & 10.0 \\
\hline & 7 & & \\
\hline \multicolumn{4}{|c|}{ Household Income(A) } \\
\hline $9,000-50,000$ & & 55 & 45.8 \\
\hline $50,000-100,000$ & & 26 & 21.7 \\
\hline $100,001-150,000$ & & 20 & 16.7 \\
\hline $150,001-200,000$ & & 11 & 9.2 \\
\hline \multirow{2}{*}{$200,001-570,000$} & & 8 & 6.7 \\
\hline & $90,200.00$ & & \\
\hline
\end{tabular}

Field survey, 2015

The mean age of the household heads was 40 years with majority being male. Over 57 percent of the household heads were over the age of 40 indicating that majority of the household heads were not so young as to be capable of using their strength to access income when compared to younger household heads. Maleness however gave opportunity of accessing resources to male more than female household heads. Most (84.2 percent) of the rural farming household heads were married. Over 90 percent of the respondents had a level of formal schooling. Education provides leverage for income generation among households and is likely to enhance household food access. The average household size was 7 persons which are large especially when compared to the Gombe state household size average of 5 persons per household (Knoema, 2016). The larger the household sizes, the higher the probability that households heads will have difficulty meeting up with the cost of adequate feeding. Table 1 also shows that almost 81 percent of the households had crop and livestock farming as the primary or major occupations, while 14.1 percent were primarily engaged in non-farm occupations. This indicates that the study area is largely an agrarian community. Household income is an important component of livelihood wellbeing of rural households. It can be deduced from the study that about 67.5 percent had household income ranges $\mathrm{N}$ 9,000- 100,000 annually. The average household income was $\mathbf{N} 90,200$. Amaza et al. (2006) noted the importance of household income in reducing the probabilities of a household being food insecure.

The result of the analysis of farm household food insecurity status is presented in Table 2 using the approach of Household Food Insecurity Access Scale (HFIAS). Result shows that about 27 percent of the respondents were food secure. In the context of this study, food secure households were those who rarely 
experienced worry about not having the resources to access enough food. The result is similar to the one obtained by Chinweoke (2015) who used HFIAS to measure household food security status in Taraba state, Nigeria and found that only 23 percent of households in his study were food secure. It can be observed from the result that a little above one fourth of the surveyed households can access food and remain food secure because they have the financial capability of accessing food.

Table 2: Household food insecurity status

\begin{tabular}{llll}
\hline $\begin{array}{l}\text { HFIAS } \\
\text { (SCORE) }\end{array}$ & $\begin{array}{l}\text { Food } \\
\text { security } \\
\text { status }\end{array}$ & Frequency & $\begin{array}{l}\text { Percentage } \\
(\%)\end{array}$ \\
\hline $0-1$ & $\begin{array}{l}\text { Food } \\
\text { secure }\end{array}$ & 32 & 26.7 \\
$2-7$ & $\begin{array}{l}\text { Mildly food } \\
\text { insecure }\end{array}$ & 42 & 35 \\
$8-14$ & $\begin{array}{l}\text { Moderately } \\
\text { food } \\
\text { insecure }\end{array}$ & 22 & 18.3 \\
$15-27$ & $\begin{array}{l}\text { Severely } \\
\text { food } \\
\text { insecure }\end{array}$ & 24 & 20 \\
\hline
\end{tabular}

Field survey, 2015

Table 2 further showed that 35 percent of the respondents were mildly food insecure. The mildly food insecure household were characterized by worrying about not having enough food in their household because they lacked resources sometimes or often. Such households could eat their preferred food but when their resources become scarce/insufficient (which happens in rare occasions), they resorted to eating a monotonous diet and/or eating some foods considered undesirable. The study also revealed that 18.3 percent of the households were moderately food insecure. A moderately food insecure household ate smaller meals sometimes or often, and/or rarely or sometimes had to cut back on quantity of food or go a whole day and night without food. Reduction in the quantity of food consumed by household is an indicator that the household is becoming food insecure (Amaza et al., 2008). Furthermore, the study revealed that 20 percent of the respondents were severely food insecure i.e. they had very poor access to food. Severely food insecure households were characterized by high HFIAS score $(15-27)$ Such households often ran out of food, went to bed hungry, and may infrequently go a whole day and night without food because they lack the resources to access food. This agrees with the findings of Idrisa et al. (2008) who observed that in Borno state, Nigeria households with inadequate or no income had the highest incidence of food insecurity.

\section{Relationship between Household Income and Household Food Access}

Table 3 shows the relationship between the income that households earn and their access to food. The result on Table 3 shows that there was positive relationship between income and access to food which was significant at $1 \%$ level of significance. Income, according to the result is a very important explanatory variable of food access with an $R^{2}$ of 0.6801 .

Table 3: Relationship between household income and household food access

\begin{tabular}{lllll}
\hline Ln Y & Coefficient & Standard error & T value & P value \\
\hline Constant & 0.4403528 & 0.2186595 & 2.01 & 0.046 \\
$\mathrm{X}$ & 0.2790664 & .0176174 & 15.84 & 0.000 \\
\hline $\mathrm{R}^{2}=0.6801$ & & & & \\
Adjusted $\mathrm{R}=0.6774$ & & &
\end{tabular}

This observation implies that as household income increases, household access to food also increases. The role of income in increasing household food security is therefore important among farming households even though they may be producing food. This is because income helps farming households increase their capacity to access food that is outside of the limit of their own production capacity, hence, increasing their power to overcome food insecurity. This conforms to findings of Agboola et al. (2008) and Ayandiji et al. (2009) who found that food insecurity was greatly reduced among households who earned additional income other than farm sources. They observed that off-farm income of rural households provided additional income sources that enabled farmers to spend more on food and other household basic needs.

\section{CONCLUSION AND RECOMMENDATION}

The study revealed that most households in the study area were headed by married, elderly, educated male farmers. There is a relationship between what households earn and the food they are able to access. In addition, the study revealed that most households suffered some level of food insecurity in terms of food access. The findings of this study underscore the need for households to engage in viable income generating activities through off-farm remunerative activities to obtain required income that will enable them afford to feed more. 
NO

\section{YES}

\begin{tabular}{|c|c|c|c|c|c|c|c|c|c|c|}
\hline \multirow{3}{*}{ Did you worry that your household would not have enough food? } & \multirow{3}{*}{ N } & \multirow{3}{*}{$\%$} & \multicolumn{2}{|c|}{ Rarely } & \multicolumn{2}{|c|}{ Sometimes } & \multicolumn{2}{|c|}{ Often } & \multicolumn{2}{|c|}{ Total Yes } \\
\hline & & & $\mathbf{N}$ & $\%$ & $\mathbf{N}$ & $\%$ & & $\%$ & $\mathbf{N}$ & $\%$ \\
\hline & & & 32 & 26.7 & 17 & 14.2 & 4 & 3.3 & 53 & 44.2 \\
\hline $\begin{array}{l}\text { Were you or any household member not able to eat the kind of } \\
\text { foods you preferred because of a lack of resources? }\end{array}$ & 30 & 25.3 & 61 & 50.8 & 21 & 17.5 & 8 & 6.7 & 90 & 75.0 \\
\hline $\begin{array}{l}\text { Did you or any household member have to eat a limited variety of } \\
\text { foods due to a lack of resources? }\end{array}$ & 34 & 28.2 & 34 & 28.3 & 38 & 31.7 & 14 & 11.7 & 86 & 71.7 \\
\hline $\begin{array}{l}\text { Did you or any household member have to eat some foods that } \\
\text { you really did not want to eat because of a lack of resources to } \\
\text { obtain other types of food? }\end{array}$ & 43 & 36.2 & 23 & 19.2 & 43 & 35.8 & 11 & 9.2 & 77 & 64.2 \\
\hline $\begin{array}{l}\text { Did you or any household member have to eat a smaller meal } \\
\text { than you felt you needed because there was not enough food? }\end{array}$ & 82 & 68.3 & 23 & 19.2 & 13 & 10.8 & 2 & 1.7 & 38 & 31.7 \\
\hline $\begin{array}{l}\text { Did you or any other household member have to eat fewer meals } \\
\text { in a day because there was not enough food? }\end{array}$ & 83 & 69.2 & 21 & 17.3 & 13 & 10.8 & 3 & 2.5 & 37 & 30.8 \\
\hline $\begin{array}{l}\text { Was there ever no food to eat of any kind in your household } \\
\text { because of lack of resources to get food? }\end{array}$ & 93 & 77.8 & 15 & 12.5 & 10 & 8.3 & 2 & 1.7 & 27 & 22.5 \\
\hline $\begin{array}{l}\text { Did you or any household member go to sleep at night hungry } \\
\text { because there was not enough food? }\end{array}$ & 113 & 94.2 & 4 & 3.3 & 2 & 1.7 & 1 & 0.8 & 7 & 5.8 \\
\hline $\begin{array}{l}\text { Did you or any household member go a whole day and night } \\
\text { without eating anything because there was not enough food? }\end{array}$ & 116 & 96.7 & 3 & 2.5 & 1 & 0.8 & 0 & 0.0 & 4 & 3.3 \\
\hline
\end{tabular}

\footnotetext{
$\mathrm{n}=120,1=$ rarely if the condition happens (once or twice), $2=$ sometimes (three to ten times) and often= (more than ten times)
} 


\section{REFERENCES}

Agboola, P.O., Awotide, D.O., Ikpia, E., Kormawa, P., Okoruwa,V.O. and Babalola, D.A.(2008) "Effect of Income Diversification Strategies on food Insecurity Status of Farming Households in Africa", A Paper prepared for presentation at the 12th EAAE Congress 'People, Food and Environments: Global Trends and European Strategies', Gent (Belgium), pp. 26-29 August 2008.

Amaza, P.S., Adejobi,A.O. and Fregene,T.(2008) "Measurement and Determinants of Food Insecurity in North Eastern Nigeria.Some Empirical Policy Guidelines", Journal of Food Agriculture and Environment 6(2), pp. 92-96.

Ayandiji, A., Ladipo, F.O., Ayansina, S.O. and Ajayi, W.O. (2009) "Effect of Income on Household food Security among Small Scale Famers In Abeokuta South Local Government of Nigeria", Proceedings of the Eighteenth Annual Congress of the Nigerian Rural Sociological Association. $16^{\text {th }}-18^{\text {th }}$ December, 2009.

Babatunde, R.O., Omotosho, O.A. and Sholatan, O.S. (2007) "Socio-Economic Characteristics and Food Security of Farming Households in Kwara State", Nigeria Pakistan Journal of Nutrition, 6(1), pp.49-58.

Bokeloh, G. G. M.,Gerster-Bentaya, S L., and Weingartner, R. (2009) "Achieving Food and Nutrition Security, Action to Meet the Global Challenge", A Training Course Reader International weiterbildung $\mathrm{GmbH}$ capacity building international(InWEnt), Germany.

Chinweoke, U. I. (2015) "Measuring Household Food Security Status in Taraba State, Nigeria" Comparing
Key Indicators. M.phl Dissertation Faculty of Economics and Management Sciences. University of Stellenbosch. UK

Fanta. (2004) "Measuring Household Food Insecurity" Workshop, April 15-16, 2004. Workshop Report Washington D.C FANTA Project, FHI 360.

FAO. (2001) "State of Food Insecurity in the World, When People Live with Hunger and Fear of Starvation", A Report Produced by Economic and Social Development Department. 2001.

FAO . (2003) "The State of Food Insecurity in the World", Rome 2003.

FAO. (2010) "The State of Food Insecurity in the World", http://www.fao.org/docrep/013/i1683e/i1683.pdf.

Idrisa, Y.L., Gwary, M.M. and Shehu, H. (2008) "Analysis of Food Security Status Among Farming Households in Jere Local Government of Borno State, Nigeria", Journal of Tropical Agriculture, Food, Environment and Extension. Vol 7 No.3, pp. 199 -205

Knoema. (2016) "World and Regional Statistics, National Data, Maps and Rankings" Retrieved from http://www.knoema.com

Maharjan, K. L. and Chhetri, A. K. (2006) "Household Food Security in Rural Areas of Nepal. Relationship Between Socio-Economic Characteristic and Food Security Status", A Paper Presented at the International Association of Agricultural Economist Conference, Gold Coast, Australia. 2006.

Oluyole, K.A. and Lawal, J.O. (2008) "An Appraisal of the impact of Agro-Services Corporation on proceedings of the $9^{\text {th }}$ international conference precision agriculture", 20-23, july, 2008.

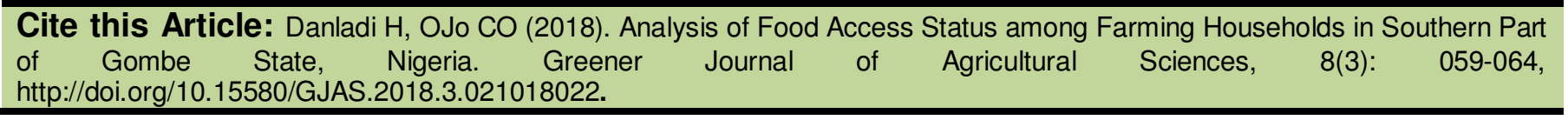

